Portland State University

PDXScholar

\title{
Interactive Physiological Responses of Nile Tilapia to Salinity- and Temperature-induced Stress: Quantifying the Coordination of Apoptosis in Oreochromis Niloticus
}

Charlee McGuire

Portland State University

Follow this and additional works at: https://pdxscholar.library.pdx.edu/honorstheses Let us know how access to this document benefits you.

\section{Recommended Citation}

McGuire, Charlee, "Interactive Physiological Responses of Nile Tilapia to Salinity- and Temperatureinduced Stress: Quantifying the Coordination of Apoptosis in Oreochromis Niloticus" (2017). University Honors Theses. Paper 469.

https://doi.org/10.15760/honors.469

This Thesis is brought to you for free and open access. It has been accepted for inclusion in University Honors Theses by an authorized administrator of PDXScholar. Please contact us if we can make this document more accessible: pdxscholar@pdx.edu. 
Interactive physiological responses of Nile tilapia to salinity- and temperature-induced stress: quantifying the coordination of apoptosis in Oreochromis niloticus

by

\section{Charlee McGuire}

An undergraduate honors thesis submitted in partial fulfillment of the

requirements for the degree of

Bachelor of Science

in

University Honors

and

Health Sciences

Thesis Adviser

Dr. Brad Buckley

Portland State University 


\title{
Interactive physiological responses of Nile tilapia to salinity- and temperature-induced stress: quantifying the coordination of apoptosis in Oreochromis niloticus A thesis submitted in partial fulfillment of the requirements for the Bachelor of Science degree In Health Sciences in Portland State University's Honors College By Charlee McGuire \\ In collaboration with B. Buckley, R. Palmer, K. Kouba, B. Burdekin, L. Williams and K. Posner in the Center for Life in Extreme Environments in the PSU Biology Department
}

\begin{abstract}
Nile tilapia provide an ideal model to study the accumulation of climate change-induced stressors due to their habitat in tropical freshwater systems that are susceptible to simultaneous saltwater intrusion and temperature fluctuation due to sea level rise. This study investigates the physiological responses of Nile tilapia to salinity- and temperature-induced stress to identify the interactive effects of simultaneous stressors on the cell cycle. Proteins indicative of cell cycle activity and arrest were quantified in the tissues of Nile tilapia exposed to various environmental conditions varying by temperature and salinity. Dot Blotting was utilized to measure Gadd45 while Western Blotting was used to confirm the identity of the protein. Results from previous investigations in the Buckley laboratory were also utilized to compare the expression patterns of Gadd45 to relevant cell activity proteins p53 and PCNA. Of the three proteins under scrutiny, a significant change in expression of p53 was observed for the interaction of salinity- and temperature- induced stress, while full strength saltwater treatment alone was found to have a significant impact on the expression of p53, Gadd45 and PCNA. This study can be used in collaboration with existing research to describe the coordination of apoptotic pathways in Nile tilapia and other non-mammalian species. These findings can be used to create effective conservation efforts for this important species both in the wild and in fisheries for public health initiatives in response to global climate change.
\end{abstract}

\section{Introduction}

The diverse mechanisms of global climate change are altering both physical landscapes as well as the physiologies of organisms adapted to various environments (Somero, 2012). The resilience of these species to even subtle changes in their niches will be of critical importance to the sustainability of ecosystems. Nile tilapia provide an ideal model through which to study the accumulation of climate disturbance as they are tropical freshwater ectotherms with a coastal river habitat that is susceptible to rising ocean levels (El-Raey, 1997). Such conditions will expose them to simultaneous salt water intrusion and temperature variability creating an environmental threat to these delicate ecosystems (Gunter \& Hildebrand, 1951). The accuracy of measuring the impacts of climate change depend on the extent to which multiple factors are taken into account on integrative levels, rather than considering only one variable at a time (Milliman, et al., 1989). Physiological research is a reasonable platform by which to perform this kind of work (Lockwood, et al., 2010). Tropical ectotherms are particularly threatened by changes in environmental temperature; as a result, these species will need to compensate by acclimatizing or shifting their distribution.

Due to the economic importance and immense amount of genetic information available for Nile tilapia (Hassan, et al., 2013), quantifying the phenomenal impacts of climate change will be crucial for the 
cultures that depend on the nutrition and economy that tilapia provide. Tilapia are the third most cultured fish in the world behind salmon and carp. The tolerance levels indicated by this research will contribute to a public health perspective for their preservation in the Nile river. They can provide a cheap and rapidly accessible food source for many communities and serve as biological controls in fighting the malaria epidemic in Eastern and Sub-Saharan African countries by feeding on vector-carrying mosquito larvae in the Nile (Howard, et al., 2007). Nile tilapia are critical for global health.

In the United States, Australia, and South Africa, tilapia are considered an invasive species. Native fauna will suffer severe consequences in terms of biodiversity if these nonnative species become established on a broad scale; therefore, predicting and understanding their capacity to do so across various conditions is essential to avoid population depletion and even local extinctions of native species (Zambrano, et al., 2006). Both the potential for economic success and the consequences of the ecological aftermath have to be considered (Zambrano, et al., 2006). Therefore, determining their tolerance levels for multiple conditions will have implications for their potential biogeographical ranges and competitors.

Determining the thresholds for temperature and salinity tolerance of Nile tilapia is an essential focus of the primary literature. Scholars have studied the effect of salinity and temperature stress in tilapia on the endocrine system (Breves, et al., 2010), glucose levels (Barcellos, et al., 1999 ), the immune response (Chebaani, et al., 2014), cortisol levels (Kammerer, et al., 2010) and growth rates (Likongwe, et al., 1996). While understanding the cellular effect of these individual parameters is fundamental, their operation in conjunction with one another has critical implications for the holistic consequences of climate change (Sardella, et al., 2004).

Previous research has determined that tilapia are unable to maintain mineral balances at environmental salinity concentrations above $18 \mathrm{ppt}$ (Fiess, et al., 2007). Seawater has a salinity concentration of $34 \mathrm{ppt}$, imposing potentially lethal impacts to the fish in their habitats when ocean levels surge and subsequently overflow into coastal freshwater rivers (Frihy, 2003). However, saltwater intrusion has been studied primarily for its relation to groundwater aquifers as opposed to freshwater organisms. Rivers in close proximity to coastal regions require more research to determine the impacts of salinity change (Roessig, et al., 2004). While some research supports the idea that organisms that are acclimated to low temperatures are more prepared to compensate for rising salinity levels by either reducing the permeability of mitochondrial membranes or by increasing the activity of ion pumps (Hurst, 2007), more research is required on the effectiveness of these mechanisms in order to support this notion. Studies have also shown that osmoregulatory failure contributes to temperature-induced mortality during environmentally realistic decreases in temperature (Atwood, et al., 2003). Therefore, understanding thermoregulatory and osmoregulatory behaviors in collaboration is important for predicting mortality.

Stress and mortality due to high salinity levels are caused by damages to cell regulating organelles called mitochondria (Berg, et al., 2012). Normally, organisms in freshwater systems are composed of more ions in their tissues than in the surrounding environment. Therefore, to maintain homeostasis and avoid losing ions to the environment, ions must be conserved while excess water is excreted. However, if a freshwater organism is exposed to saltwater, their environment is composed of more ions than their cells, requiring the organism to compensate by conserving water and excreting ions. If this attempt is unsuccessful, cell 
shrinkage occurs and causes damage to the mitochondrial membrane located inside. Additionally, the increased salinity level can begin to denature proteins and an apoptotic pathway will ensue to avoid replication of damaged DNA. Mortality due to low temperature is caused primarily by the thermal stress associated with Winter Stress Syndrome, causing many 'winterkills' of tilapia and other freshwater species (Hurst, 2007). While fish with larger body mass have been shown to be more resilient to Winter Stress, the optimal temperature for Nile tilapia is between $25-28{ }^{\circ} \mathrm{C}$, with reproduction ceasing at $22^{\circ} \mathrm{C}$, feeding stopping at $20^{\circ} \mathrm{C}$, and total mortality at $8.6^{\circ} \mathrm{C}$ (Charo-Karisa, et al., 2005). Osmoregulatory abilities along with mitochondria become impaired during Winter Stress (Schmidt-Nielsen, 1997), making gill tissue an ideal specimen to study as the osmoregulatory and adaptive capacity of tilapia depend largely on the function of the gills (Güner, et al., 2006). Inadequate maintenance of homeostasis can lead to cell rigidity and eventual apoptosis.

The apoptotic pathway that evokes programmed cell death depends on the recognition of DNA damage by p53, which can activate proteolytic enzymes to degenerate cells (Reynolds, 2015). One of these enzymes is Gadd45 (Chen, et al., 1995), the protein of interest in the current study. The extent to which growth suppression is occurring may therefore be indicated by the presence of Gadd45 (Vairapandi, et al., 2000). Previous investigations in the Buckley laboratory have used both proliferating cell nuclear antigen, or PCNA, and the p53 tumor suppressor as reliable markers for measuring cell division and apoptosis in the same treatment groups as the current study. Replication of DNA will only occur with the absence of p53 along with high concentrations of PCNA initially during the S-phase followed by the $\mathrm{G}_{1}$-phase of the cell cycle (Paunesku, et al., 2001). However, if PCNA levels are high in the presence of $\mathrm{p} 53$, this is an indication of DNA repair due to disturbance or trauma, and if PCNA is in low levels or absent, this is an indication of apoptosis and lack of cell division (Paunesku, et al., 2001). Therefore, levels of p53 and PCNA in comparison to one another serve as markers of cell activity, and Gadd45 is a protein that has been shown in mammals to regulate their interaction (Xu \& Morris, 1999). Gadd45 is induced by p53 once damage is detected and binds to PCNA to inactivate it, ceasing cell replication (Smith, et al., 1994). While the association between the expression of Gadd45 and growth suppression has been well documented in mammalian species (Hall, et al., 1995), it is not clearly documented in fish species, making it a topic of interest for fish physiologists. Measuring this protein is therefore an ideal route by which to examine the coordination of the fate of a cell: replication, repair, or death.

\section{Specific Aims}

Primarily, our study aims to identify the interactive effects of temperature and salinity stress on the cell cycle in Nile tilapia. Multiple stress tests were conducted, exposing the tilapia to varying degrees of salinity and temperature, and the trends observed across the groups were compared to determine the predictors of cell cycle progression versus arrest in the given conditions. We hypothesize that the additive effect of temperature and salinity stress on apoptosis will be greater than the effect of either stressor independently.

Secondly, our study aims to identify indicators for cell cycle progression and cell cycle arrest and establish these as reliable markers to be used in future studies on Nile tilapia and other non-mammalian species. If the observed relationship between the previously studied proteins p53 and PCNA with Gadd45 exhibits a trend similar to that which would be expected in mammalian species due to the above described 
interaction, Gadd45 can become established as a reliable sign of the stress response in fish species. We hypothesize that cells subjected to milder temperature or salinity conditions will express lower Gadd45 concentrations compared to cells subjected to more drastic conditions.

\section{Method}

Animal Rearing

Hatchery raised mixed sex Oreochromis niloticus were reared at Portland State University at $22{ }^{\circ} \mathrm{C}$ and fed an ad-lib diet of commercial feed consisting of crude protein (45\%), crude fat (11\%), and crude fiber $(2 \%)$.

\section{Experimental Treatments}

All experiments were conducted following the guidelines set by the Institutional Animal Care and Use Committee, or IACUC. Fish were transferred to a total of six treatment tanks, with 10 fish per tank, totalling 60 fish. One tank was used for a control of $22{ }^{\circ} \mathrm{C}$ and $0 \mathrm{ppt}$ (warm freshwater, notated as WF), which keeps constant the stress induced by handling across all treatments (Chen, et al., 2002), while the other five treatments consisted of $22^{\circ} \mathrm{C}$ and $16 \mathrm{ppt}$ (warm brackish water, notated as WB), $22{ }^{\circ} \mathrm{C}$ and 34 ppt (warm saltwater, notated as WS), $14^{\circ} \mathrm{C}$ and $0 \mathrm{ppt}$ (cold freshwater, notated as $\mathrm{CF}$ ), $14^{\circ} \mathrm{C}$ and $16 \mathrm{ppt}$ (cold brackish water, notated as $\mathrm{CB}$ ), and $14^{\circ} \mathrm{C}$ and $34 \mathrm{ppt}$ (cold saltwater, notated as CS). Fish were held in the treatment tanks for 60 minutes, then euthanized via hypothermic shock induced by rapid chilling followed by severing of the spinal cord. Tissue samples from the brain, heart, gill, liver, spleen and white muscle were collected from each fish. Post-collection, all tissue samples were stored at $-80^{\circ} \mathrm{C}$.

\section{Tissue Quantification}

Frozen tissue samples were thawed, then placed in $100 \mu$ of homogenization buffer, heated at $100{ }^{\circ} \mathrm{C}$ for 5 minutes and centrifuged for 10 minutes at $12000 \mathrm{x}$ g. Protein content was then quantified by the Bradford assay (Buckley, et al., 2006).

\section{Western Blots}

Replicating the literature (Sleadd, et al., 2014), the specificity of the antibodies used to detect the proteins under scrutiny were determined using the Western blotting technique. SDS-polyacrylamide gel electrophoresis was used to isolate $10 \mu \mathrm{l}$ of protein from each sample. The proteins were transferred onto a nitrocellulose membrane by electroblotting overnight. Blots were then soaked for 1 hour in $5 \%$ non-fat dry milk (NFDM) in 1 X PBS (blocking buffer) while shaking constantly. Blots were washed in 1 X PBS containing $0.1 \%$ Tween 20 for five minutes. After three washes, blots were incubated in primary antibody (primary antibodies used include Gadd45, p53, and PCNA, Bio-Rad) at a 1:1000 dilution in blocking buffer overnight, followed by washing for ten minutes in $1 \mathrm{X}$ PBS. After three washes, blots were saturated with the secondary antibody (Goat Anti-Rabbit, Bio-Rad) at a 1:5000 dilution in blocking buffer. Then, blots were washed six times in 1 X PBS for five minutes. Blots were exposed to enhanced chemiluminescent reagent (ECL, Amersham, Piscataway, NJ, USA) for five minutes. The blots were wrapped in plastic wrap and exposed to X-ray film (XOMAT-AR film, Kodak, Rochester, NY, USA). The presence of the proteins of interest was then confirmed by size using the protein standard. 


\section{Dot Blots}

Replicating the literature (Buckley, et al., 2006), $1 \mu \mathrm{g}$ protein samples in a final volume of $100 \mu \mathrm{l}$ in phosphate-buffered saline (1 X PBS) were bound directly to nitrocellulose membranes with a BioDot ${ }^{\circledR}$ apparatus (Bio-Rad, Hercules, CA, USA). Following the 45 minute blotting period, membranes were dried at $70^{\circ} \mathrm{C}$ for 30 minutes. Blots were then soaked for 1 hour in $5 \%$ non-fat dry milk (NFDM) in $1 \mathrm{X}$ PBS (blocking buffer) while shaking constantly. Blots were washed in 1 X PBS for five minutes. After three washes, blots were incubated in primary antibody (primary antibodies used include Gadd45, p53, and PCNA, Bio-Rad) at a 1:3000 dilution in blocking buffer overnight. The blots were then washed for ten minutes in $1 \mathrm{X}$ PBS. After three washes, blots were saturated with the secondary antibody (Goat Anti-Rabbit, Bio-Rad) at a 1:3000 dilution in blocking buffer. Then, blots were washed six times in $1 \mathrm{X}$ PBS for five minutes. Blots were exposed to enhanced chemiluminescent reagent (ECL, Amersham, Piscataway, NJ, USA) for five minutes. The blots were wrapped in plastic wrap and exposed to X-ray film (XOMAT-AR film, Kodak, Rochester, NY, USA) and the film was developed for densitometry analysis.

\section{Densitometry}

Densitometry was conducted on the dot blots to determine relative concentrations of protein using Image J software (NIH Freeware). The density of each dot was measured, and triplicates were averaged to obtain the average density of each sample. All values were standardized to the control values.

\section{Statistics}

To identify groups for which the expression patterns for the protein of interest showed a significant effect of treatment, 2-way ANOVA analysis via the RStudio software (RStudio, Inc., Boston Massachusetts, USA) was used. Normal distribution and equal variance were obtained through a log transformation applied to the data. The value of 1 was added to each sample value prior to the log transformation to avoid the generation of negative values. Using Tukey's honest significant difference (HSD) post hoc test, the dataset was analyzed. Results with a p-value $<0.05$ were considered significant and designated with distinguishing group letters in the figures included in the next section.

\section{Results}

Triplicate samples from each treatment group were compared to produce the following results. The group for which the expression pattern for Gadd45 showed a significant effect of treatment was the WS group, when compared to all other groups except the control (see Figure 1). This group displayed statistically significant decreases in Gadd45 when compared to the WB group (p-value: 0.0474206), the CF group (p-value: 0.0250140 ), the CB group (p-value: 0.0352271 ) and the CS group (p-value: 0.0002506$)$. When the outliers of the WS treatment were removed, a statistical difference was observed between the WS treatment and the control, as well as all of the treatment groups (see Figure 2). This group displayed statistically significant decreases in Gadd45 when compared to the control group (p-value: 0.0055052), the WB group (p-value: 0.0004801), the CF group (p-value: 0.0001996$)$, the CB group (p-value: 0.0003177) and the CS group (p-value: 0.0000007 ). The cold water treatment groups elicited no significant change in Gadd45 concentration compared to the control (see Figures 1 and 2). 
When compared to the control, the treatment groups for which the expression for $\mathrm{p} 53$ showed a significant decrease were the WS treatment, the CB treatment, and the CS treatment (see Figure 3, Palmer \& Buckley, in preparation, 2017). Additionally, the treatment group for which the expression pattern for PCNA showed a significant effect of treatment compared to the control was the WS group, which exhibited a statistical decrease in protein (see Figure 4, Palmer \& Buckley, in preparation, 2017).

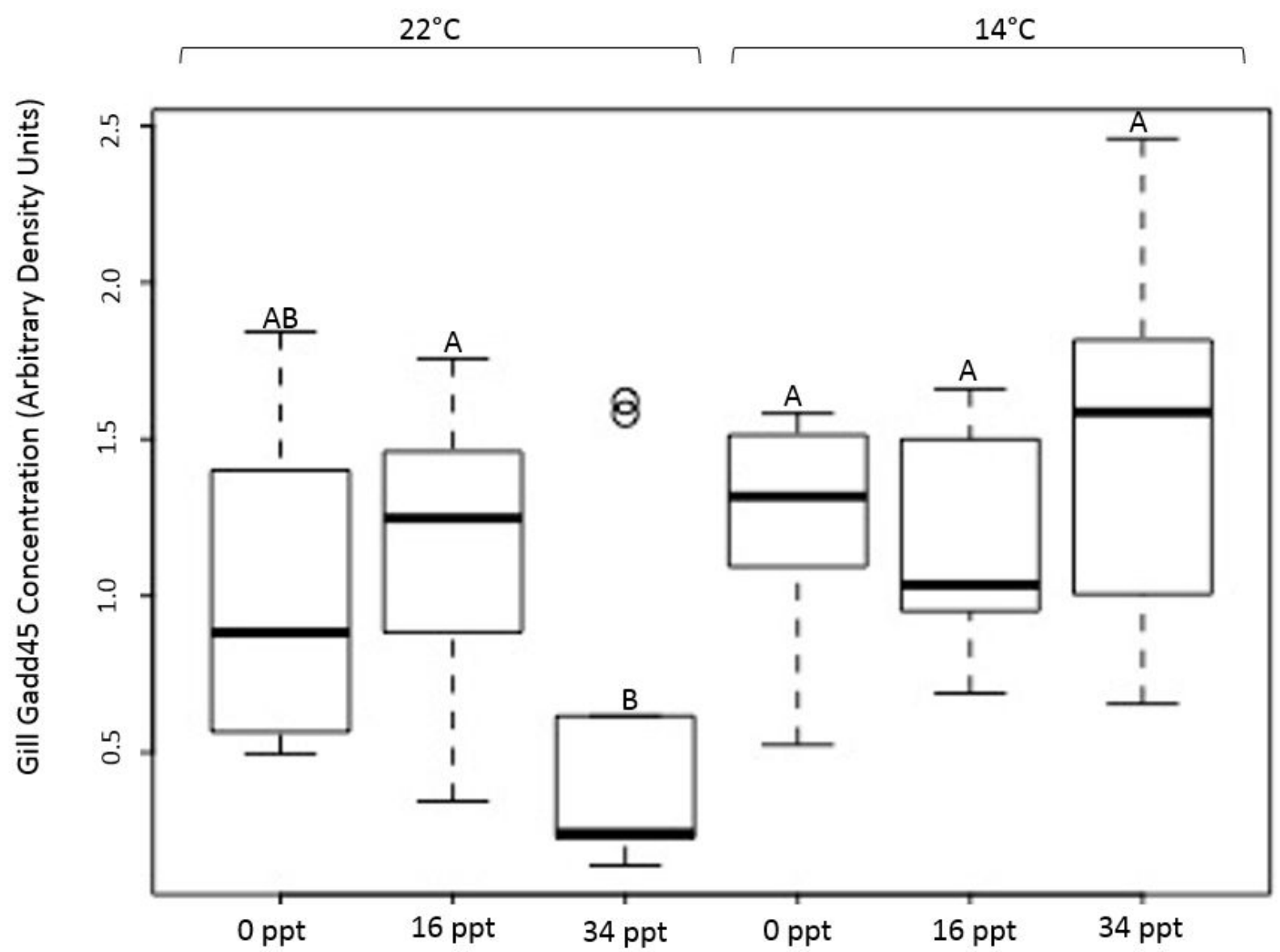

Figure 1. Box plot of gill Gadd45 concentrations by treatment group: $22^{\circ} \mathrm{C} / 0 \mathrm{ppt}(\mathrm{WF}), 22{ }^{\circ} \mathrm{C} / 16 \mathrm{ppt}$ (WB), $22{ }^{\circ} \mathrm{C} / 34 \mathrm{ppt}$ (WS, with outliers indicated by rings), $14^{\circ} \mathrm{C} / 0 \mathrm{ppt}(\mathrm{CF}), 14^{\circ} \mathrm{C} / 16 \mathrm{ppt}(\mathrm{CB})$, and $14^{\circ} \mathrm{C} / 34 \mathrm{ppt}(\mathrm{CS})$ 


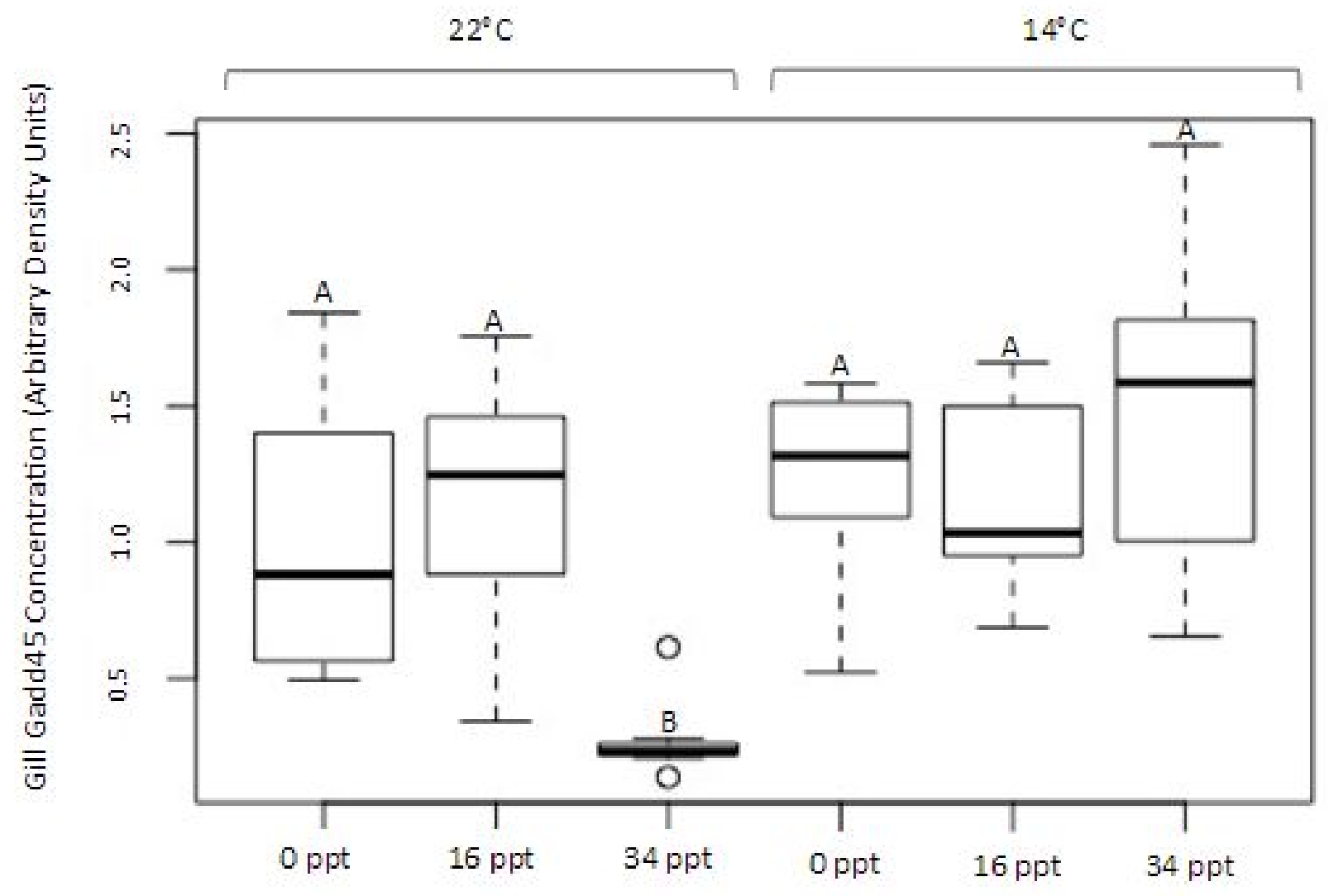

Figure 2. Box plot of gill Gadd45 concentrations by treatment group: $22{ }^{\circ} \mathrm{C} / 0 \mathrm{ppt}$ (WF), $22{ }^{\circ} \mathrm{C} / 16 \mathrm{ppt}$ (WB), $22^{\circ} \mathrm{C} / 34 \mathrm{ppt}$ (WS, without outliers), $14^{\circ} \mathrm{C} / 0 \mathrm{ppt}(\mathrm{CF}), 14^{\circ} \mathrm{C} / 16 \mathrm{ppt}(\mathrm{CB})$, and $14^{\circ} \mathrm{C} / 34 \mathrm{ppt}(\mathrm{CS})$ 


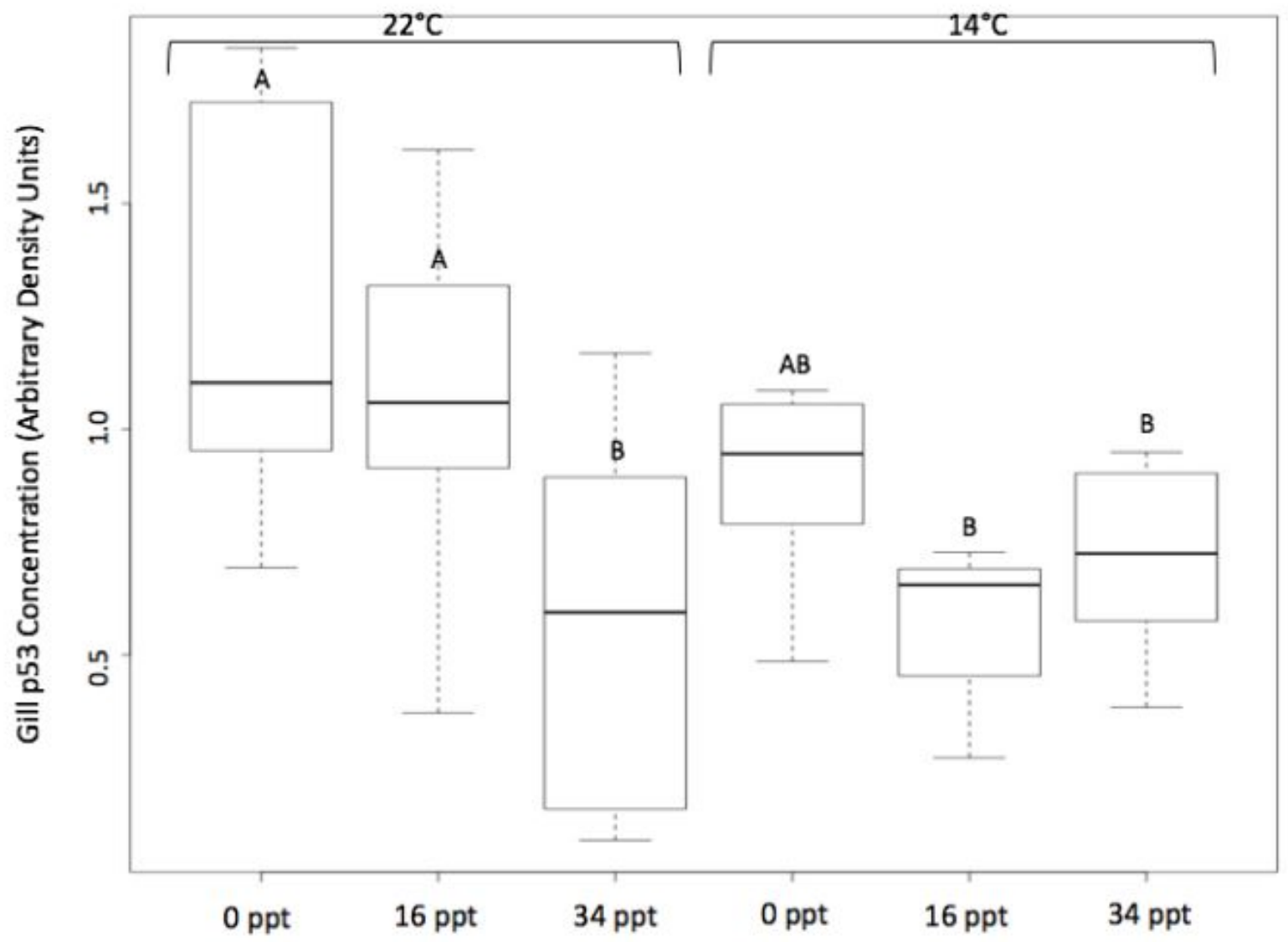

Figure 3. Box plot of gill p53 concentrations by treatment group: $22^{\circ} \mathrm{C} / 0 \mathrm{ppt}(\mathrm{WF}), 22{ }^{\circ} \mathrm{C} / 16 \mathrm{ppt}$ (WB), $22^{\circ} \mathrm{C} / 34 \mathrm{ppt}(\mathrm{WS}), 14^{\circ} \mathrm{C} / 0 \mathrm{ppt}(\mathrm{CF}), 14^{\circ} \mathrm{C} / 16 \mathrm{ppt}(\mathrm{CB})$, and $14^{\circ} \mathrm{C} / 34 \mathrm{ppt}(\mathrm{CS})$; this data originates from a publication in preparation by Palmer, R. \& Buckley, B (2017) 


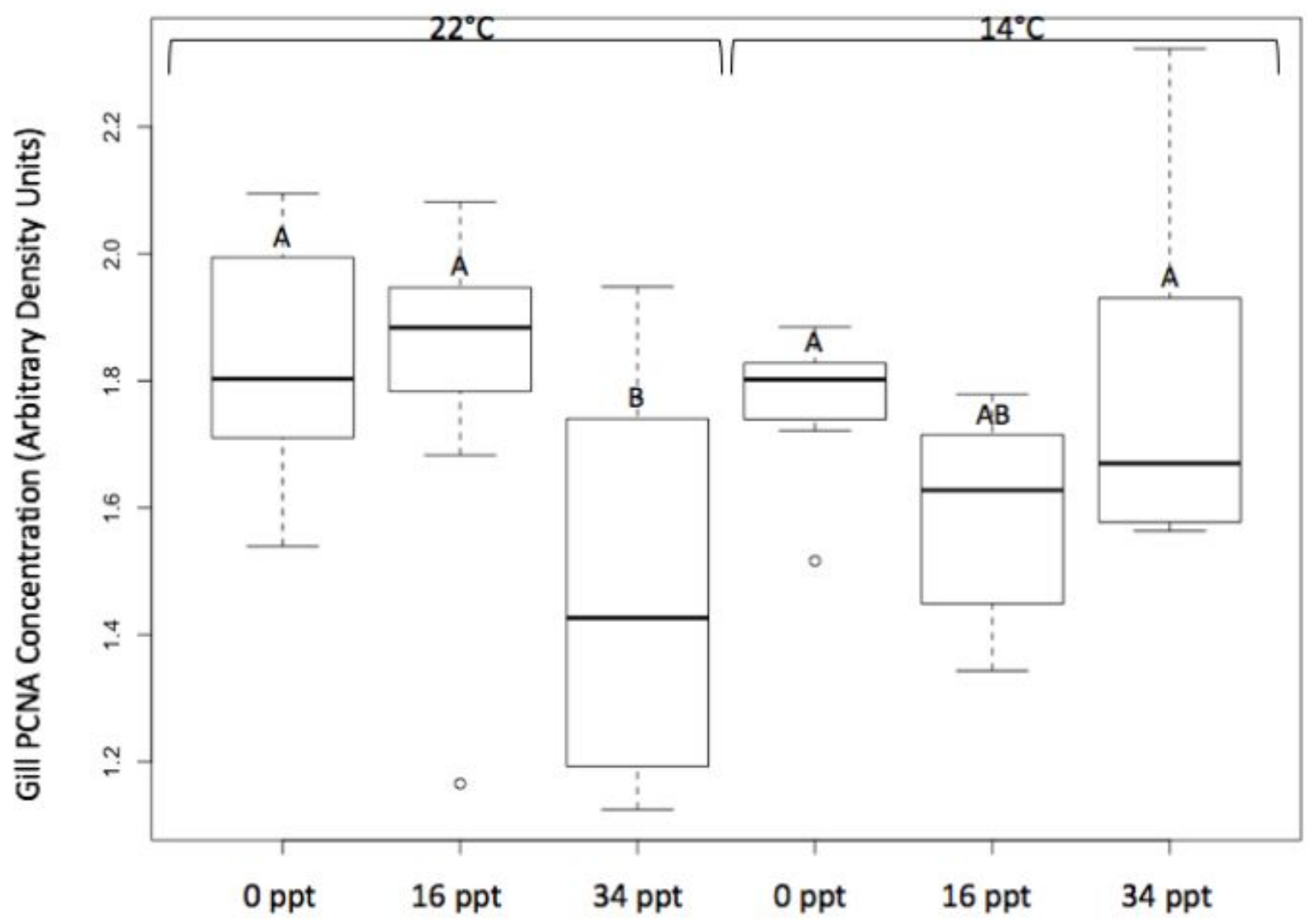

Figure 4. Box plot of gill PCNA concentrations by treatment group: $22^{\circ} \mathrm{C} / 0 \mathrm{ppt}(\mathrm{WF}), 22^{\circ} \mathrm{C} / 16 \mathrm{ppt}$ (WB), $22{ }^{\circ} \mathrm{C} / 34 \mathrm{ppt}(\mathrm{WS}), 14^{\circ} \mathrm{C} / 0 \mathrm{ppt}(\mathrm{CF}), 14^{\circ} \mathrm{C} / 16 \mathrm{ppt}(\mathrm{CB})$, and $14^{\circ} \mathrm{C} / 34 \mathrm{ppt}(\mathrm{CS})$; this data originates from a publication in preparation by Palmer, R. \& Buckley, B (2017)

\section{Discussion}

The control treatment is reflective of the tropical freshwater habitats in which Nile tilapia generally thrive. Therefore, the high amount of variation indicated by the wide error bars in Figure 1 in the control group is likely due to the differences in base levels of protein present in the fish due to variations in size or genetic diversity. However, the WS treatment group in the Gadd45 trial had narrower error bars compared to all other groups, signaling a universal effect of this treatment: the expression patterns of the fish are being diverted to address the stress of the treatment. While this treatment group was the only one in which a significant change in Gadd45 was observed, we predict that conducting the trials again with more fish would result in a significant change between the control treatment and the WS group, as the variability would decrease between fish in the control group. The current dataset does however suggest that a change from WB to WS will trigger a decrease in Gadd45. This may suggest that Nile tilapia are able to tolerate fluctuations in salinity up to brackish water, but their osmoregulatory abilities are hindered in full strength saltwater, or that the exposure would need to be lengthened in order to observe a more significant change in osmoregulatory capabilities of the fish in the WB treatment over time. When the outliers of the WS treatment were removed, a statistically significant decrease was observed in the WS treatment when compared to the control as well as all of the other treatment groups (see Figure 2). The size of the box plot 
and error bars for the WS treatment group became considerably condensed when the two outliers were removed, resulting in a significant difference observed between the control and the treatment in contrast to Figure 1. This result is supportive of the argument that Nile tilapia are tolerant of increases in salinity levels up to brackish water, with osmoregulatory capabilities becoming thwarted in saltwater.

The observed decrease in Gadd45 was inconsistent with our original prediction that Gadd45 concentration would increase during the onset of stress, as it is induced by p53 following the recognition of DNA damage. It is possible that this is due to the preoccupation of the protein with binding to active sites on PCNA to cease DNA replication; therefore, the protein would be less bioavailable for binding to our antibodies and would exhibit a lower concentration as it becomes less detectable. Additionally, as the protein is being utilized, the translation of new protein has likely not yet caught up to the demands of the stress response. Accordingly, we would expect to see an increase in Gadd45 if the exposure was lengthened as the nuclei of the cells generate more proteins that are essential for a sufficient stress response and growth suppression.

The notion that there is a lack of availability of the proteins of interest due to active recruitment and binding to their respective targets is consistent with the p53 trials, as there were statistically significant decreases observed as compared to the controls for the WS, CB and CS treatments (see Figure 3). This supports the theory that the protein is being rapidly employed for the stress response. Additionally, because PCNA exhibited a significant decrease in concentration in the same treatment group (WS) that Gadd45 was likely to be most actively binding (see Figure 4), this is consistent with the idea that PCNA activity and DNA replication is inhibited by the presence and binding of Gadd45. A conformational change in PCNA occurs when bound to Gadd45, thereby altering its distinguishability for the antibodies.

In the cold water treatments, increases in salinity had no effect on Gadd45 (see Figures 1 and 2). This indicates that the expression of Gadd45 in response to salinity is somehow altered at colder temperatures, because there was an effect observed in response to saltwater alone with no temperature-induced stress. Enzymes that are important for the response to trauma on tissues have ideal temperatures for which they perform efficiently, and these reactions likely take longer at below optimal temperatures, or even become inhibited. Therefore, it is probable that the effect of temperature is more dependent on the length of exposure. We predict that an increase in the duration of time spent in the cold water conditions would likely produce significant changes in Gadd45 to account for the decreased reaction times, subsequently causing significant changes in PCNA concentration in the cold treatments as well. Furthermore, because tilapia are constantly regulating their internal environment to preserve ions and excrete excess water to maintain homeostasis in freshwater systems, this could account for the more rapidly induced response to salinity stress when compared to temperature stress as they are accustomed to making such adjustments. These results indicate that Nile tilapia may struggle to induce an adequate stress response to recover from trauma when exposed to colder temperatures in their tropical environments during times of Winter Stress.

Due to the trends observed in the expression of Gadd 45 in relation to p53 and PCNA in response to the treatments, the dataset suggests that Gadd45 is indeed induced by 553 to inhibit PCNA, as their concentration trends in the treatment groups were correlated to support this mechanism. Therefore, the coordination of the apoptotic pathway in Nile tilapia and potentially even other non-mammalian species 
reasonably depends on the communication that Gadd45 provides between p53 and PCNA. This is similar to the relationship observed in the literature on mammalian species. The results of this experiment are the foundational steps in determining how the concentration of Gadd45 is altered as Nile tilapia experience the interaction of fluctuations in environmental temperature and salinity, thereby establishing this protein as an index for quantifying the stress response and coordination of apoptosis. While the present results are only indicative of an interactive effect of temperature and salinity on the expression of p53 and not Gadd45 nor PCNA, future trials are necessary to determine the tolerance of Nile tilapia to the simultaneous and long-term impacts of climate change.

Following the stress tests, many opportunities for further research arise. Firstly, running the same set of tests with longer exposure durations will generate a greater understanding about the timing of the mechanisms involved in the stress response. We predict that the cold treatments will likely see more significant changes in protein concentration if the stress response is given more time to activate. Furthermore, we predict that if mRNA was quantified, we would likely see an increase in the tissues of the fish exposed to simultaneous stressors as proteins are produced at faster rates than usual to account for the stress response. These trials in conjunction would provide more insight into the coordination of the stress response in regards to protein recruitment and activation. Additionally, while pre-acclimation to environmental isotonicity has been shown to have little effect on improving Nile tilapia's tolerance to decreasing temperatures (Atwood, et al., 2003), the reverse acclimation strategy could be investigated to determine if pre-acclimation to cold temperature improves the tolerance of tilapia exposed to increasing salinity levels. This trial will give insight into the difference in stress response in tilapia between simultaneously exposed stressors and stressors that are introduced gradually and at varying times. It may also have implications for Nile tilapia's biological priorities during times of abiotic stress, such as how their energy is preserved and their resources allocated, whether that be towards osmoregulatory or thermoregulatory behaviors.

Further tests to determine the impact of body size, development and chronological age on the accumulation of stress responses will also be logical extensions of the current study. According to previous research, salinity tolerance can increase linearly with body size. However, this is likely due to the ontogenetic development of the hypo osmoregulatory system and increases in hemoglobin's affinity for oxygen as opposed to the physical surface area to volume ratio of the fish (Watanabe, et al., 1985). As the tilapia age, their hemoglobin develops higher affinity for oxygen, making them more tolerant to both warmer and more saline environments, as these conditions have the lowest dissolved oxygen content (Watanabe, et al., 1985). Lastly, studies that compare tolerance of increasing salinity levels between tilapia that are hatched in elevated salinity environments to those that were hatched in freshwater environments and later transferred to elevated salinity will shed light on the ability of Nile tilapia to acclimate to the changing climate over generations (Watanabe, et al., 1985). Therefore, investigating body size, development and chronological age versus the ability to resist changes in environmental salinity and temperature will provide further information about the individuals who will be most vulnerable to the consequences of climate change. 


\section{Conclusion}

The aim of this study was to obtain evidence of the impact of the interaction between climate-induced stressors on the activity of the cell cycle and physiological responses in Nile tilapia. The interaction of salinity and temperature stress was only found to have a significant impact on the expression of p53, while full strength saltwater treatment alone with no temperature-induced stress was found to have a significant impact on the expression of p53, Gadd45 and PCNA. The results are supportive for the use of these proteins as reliable parameters for measuring organismal stress and the coordination of apoptosis in future trials with Nile tilapia. Tilapia's tolerance across projected environmental conditions that are imposed by the mechanisms of climate change were examined and have implications for their potential to thrive in particular ecosystems. Due to the lack of existing comprehensive research on the impact of multiple stress parameters on tilapia, this study will contribute to the body of aquaculture literature and the increasingly urgent data on the physiological, economic and cultural consequences of climate change. Lastly, the findings can be used to inform policy regarding the preservation of this species both in their native habitats and in fisheries to sustainably manage an important global nutrition source.

\section{References}

Atwood, H. L., Tomasso, J. R., Webb, K., \& Gatlin, D. M. (2003). Low-temperature tolerance of Nile tilapia, Oreochromis niloticus: effects of environmental and dietary factors. Aquaculture Research, 34(3), 241-251.

Barcellos, L. J., Nicolaiewsky, S., De Souza, S. M., \& Lulhier, F. (1999). The effects of stocking density and social interaction on acute stress response in Nile tilapia Oreochromis niloticus (L.) fingerlings. Aquaculture Research,30(11-12), 887-892.

Berg, J. M., Tymoczko, J. L., \& Stryer, L. (2012). Biochemistry. New York: W.H. Freeman.

Breves, J. P., Hasegawa, S., Yoshioka, M., Fox, B. K., Davis, L. K., Lerner, D. T., ... \& Grau, E. G. (2010). Acute salinity challenges in Mozambique and Nile tilapia: differential responses of plasma prolactin, growth hormone and branchial expression of ion transporters. General and comparative endocrinology, 167(1), 135-142.

Buckley, B. A., Gracey, A. Y., \& Somero, G. N. (2006). The cellular response to heat stress in the goby Gillichthys mirabilis: a cDNA microarray and protein-level analysis. Journal of Experimental Biology, 209(14), 2660-2677.

Charo-Karisa, H., Rezk, M. A., Bovenhuis, H., \& Komen, H. (2005). Heritability of cold tolerance in Nile tilapia, Oreochromis niloticus, juveniles. Aquaculture, 249(1), 115-123.

Chebaani, N., Guardiola, F. A., Sihem, M., Nabil, A., Oumouna, M., Meseguer, J., ... \& Cuesta, A. (2014). Innate humoral immune parameters in Tilapia zillii under acute stress by low temperature and crowding. Fish physiology and biochemistry, 40(3), 797-804.

Chen, I. T., Smith, M. L., O'Connor, P. M., \& Fornace Jr, A. J. (1995). Direct interaction of Gadd45 with 
PCNA and evidence for competitive interaction of Gadd45 and p21Waf1/Cip1 with PCNA. Oncogene, 11(10), 1931-1937.

Chen, W., Sun, L., Tsai, C., Song, Y., \& Chang, C. (2002). Cold-Stress Induced the Modulation of Catecholamines, Cortisol, Immunoglobulin M, and Leukocyte Phagocytosis in Tilapia. General and Comparative Endocrinology, 126(1), 90-100. doi:10.1006/gcen.2001.7772

El-Raey, M. (1997). Vulnerability assessment of the coastal zone of the Nile delta of Egypt, to the impacts

of sea level rise. Ocean \& coastal management, 37(1), 29-40.

Fiess, J. C., Kunkel-Patterson, A., Mathias, L., Riley, L. G., Yancey, P. H., Hirano, T., \& Grau, E. G. (2007). Effects of environmental salinity and temperature on osmoregulatory ability, organic osmolytes, and plasma hormone profiles in the Mozambique tilapia (Oreochromis mossambicus). Comparative Biochemistry and Physiology Part A: Molecular \& Integrative Physiology, 146(2), 252-264.

Frihy, O. E. (2003). The Nile delta-Alexandria coast: vulnerability to sea-level rise, consequences and adaptation. Mitigation and Adaptation Strategies for Global Change, 8(2), 115-138.

Güner, Y., Özden, O., Çağirgan, H., Altunok, M., \& Kizak, V. (2006). Effects of salinity on the osmoregulatory functions of the gills in Nile tilapia (Oreochromis niloticus). Turkish Journal of Veterinary and Animal Sciences,29(6), 1259-1266.

Gunter, G., \& Hildebrand, H. H. (1951). Destruction of Fishes and Other Organisms on the South Texas Coast by the Cold Wave of January 28-February 3, 1951. Ecology, 32(4), 731-736.

Hall, P. A., Kearsey, J. M., Coates, P. J., Norman, D. G., Warbrick, E., \& Cox, L. S. (1995). Characterisation of the interaction between PCNA and Gadd45. Oncogene, 10(12), 2427-2433.

Hassan, B., El-Salhia, M., Khalifa, A., Assem, H., Al Basomy, A., \& El-Sayed, M. (2013). Environmental isotonicity improves cold tolerance of Nile tilapia, Oreochromis niloticus, in Egypt. The Egyptian Journal of Aquatic Research,39(1), 59-65.

Howard, A. F., Zhou, G., \& Omlin, F. X. (2007). Malaria mosquito control using edible fish in western Kenya: preliminary findings of a controlled study. BMC public health, 7(1), 1.

Hurst, T. P. (2007). Causes and consequences of winter mortality in fishes.Journal of Fish Biology, 71(2), 315-345.

Kammerer, B. D., Cech, J. J., \& Kültz, D. (2010). Rapid changes in plasma cortisol, osmolality, and respiration in response to salinity stress in tilapia (Oreochromis mossambicus). Comparative Biochemistry and Physiology Part A: Molecular \& Integrative Physiology, 157(3), 260-265. 
Likongwe, J. S., Stecko, T. D., Stauffer, J. R., \& Carline, R. F. (1996). Combined effects of water temperature and salinity on growth and feed utilization of juvenile Nile tilapia Oreochromis niloticus (Linneaus). Aquaculture, 146(1), 37-46.

Lockwood, B. L., Sanders, J. G., \& Somero, G. N. (2010). Transcriptomic responses to heat stress in invasive and native blue mussels (genus Mytilus): molecular correlates of invasive success. Journal of Experimental Biology, 213(20), 3548-3558.

Milliman, J. D., Broadus, J. M., \& Gable, F. (1989). Environmental and economic implications of rising sea level and subsiding deltas: the Nile and Bengal examples. Ambio, 340-345.

Paunesku, T., Mittal, S., Protić, M., Oryhon, J., Korolev, S. V., Joachimiak, A., \& Woloschak, G. E. (2001). Proliferating cell nuclear antigen (PCNA): ringmaster of the genome. International journal of radiation biology, 77(10), 1007-1021.

Reynolds, A. C. (2015). The Physiological Stress Response caused by Hypoxia and Reperfusion Injury in Striped Bass (Morone saxatilis) and Nile Tilapia (Oreochromis niloticus). Electronic Theses \& Dissertations, Georgia Southern University, Paper 1346.

Roessig, J. M., Woodley, C. M., Cech Jr, J. J., \& Hansen, L. J. (2004). Effects of global climate change on marine and estuarine fishes and fisheries. Reviews in Fish Biology and Fisheries, 14(2), 251-275.

Sardella, B. A., Cooper, J., Gonzalez, R. J., \& Brauner, C. J. (2004). The effect of temperature on juvenile Mozambique tilapia hybrids (Oreochromis mossambicus x O. urolepis hornorum) exposed to full-strength and hypersaline seawater. Comparative Biochemistry and Physiology Part A: Molecular \& Integrative Physiology, 137(4), 621-629.

Schmidt-Nielsen, Knut. (1997). Animal physiology: adaptation and environment. Cambridge University Press.

Sleadd, I. M., Lee, M., Hassumani, D. O., Stecyk, T. M., Zeitz, O. K., \& Buckley, B. A. (2014). Sub-lethal heat stress causes apoptosis in an Antarctic fish that lacks an inducible heat shock response. Journal of thermal biology,44, 119-125.

Smith, M. L., Chen, I. T., Zhan, Q., Bae, I., Chen, C. Y., Gilmer, T. M., ... \& Fornace Jr, A. J. (1994). Interaction of the p53-regulated protein Gadd45 with proliferating cell nuclear antigen. Science, 1376-1380.

Somero, G. N. (2012). The physiology of global change: linking patterns to mechanisms. Annual Review of Marine Science, 4, 39-61. 
Vairapandi, M., Azam, N., Balliet, A. G., Hoffman, B., \& Liebermann, D. A. (2000). Characterization of MyD118, Gadd45, and proliferating cell nuclear antigen (PCNA) interacting domains: PCNA impedes MyD118 and Gadd45-mediated negative growth control. Journal of Biological Chemistry, 275(22), 16810-16819.

Watanabe, W. O., Kuo, C., \& Huang, M. (1985). Salinity tolerance of Nile tilapia fry (Oreochromis niloticus), spawned and hatched at various salinities. Aquaculture, 48(2), 159-176. doi:10.1016/0044-8486(85)90102-4

Watanabe, W. O., Kuo, C., \& Huang, M. (1985). The ontogeny of salinity tolerance in the tilapias Oreochromis aureus, O. niloticus, and an O. mossambicus $\times$ O. niloticus hybrid, spawned and reared in freshwater. Aquaculture, 47(4), 353-367. doi:10.1016/0044-8486(85)90220-0

Xu, J., \& Morris, G. F. (1999). p53-mediated regulation of proliferating cell nuclear antigen expression in cells exposed to ionizing radiation. Molecular and cellular biology, 19(1), 12-20.

Zambrano, L., Martínez-Meyer, E., Menezes, N., \& Peterson, A. T. (2006). Invasive potential of common carp ( Cyprinus carpio ) and Nile tilapia (Oreochromis niloticus ) in American freshwater systems. Canadian Journal of Fisheries and Aquatic Sciences, 63(9), 1903-1910. doi:10.1139/f06-088 